\title{
ANALISIS PENGARUH DEBT RATIO DAN DEBT TO EQUITY RATIO TERHADAP RETURN ON EQUITY PERUSAHAAN PROPERTY DAN REAL ESTATE DI BURSA EFEK INDONESIA
}

\author{
Moh. Zaki Kurniawan \\ Fakultas Ekonomi Universitas Islam Balitar, Blitar \\ email: zaki.kurniawan3@gmail.com
}

Tujuan penelitian ini untuk mengetahui pengaruh variabel Debt Ratio (DR) dan Debt to Equity Ratio (DER) baik secara parsial mapun secara simultan terhadap variabel Return On Equity (ROE). Jenis penelitian yang digunakan explanatory research. Jumlah populasi 46 perusahaan dan diambil sampel 11 perusahaan. Analisis data yang digunakan yaitu, statistik deskriptif, uji asumsi klasik, dan analisis regresi berganda. Hasil penelitian menunjukkan secara parsial variabel $D R$ maupun $D E R$ berpengaruh signifikan terhadap $R O E$. Secara simultan variabel $D R$ dan $D E R$ berpengaruh signifikan terhadap $R O E$.

\section{PENDAHULUAN}

Keputusan pendanaan mencangkup sumber dana yang dapat berasal dari dana internal atau dana eksternal, besarnya utang dan modal sendiri, serta tipe utang dan modal yang akan digunakan. Utang merupakan salah satu alternatif dalam pemenuhan kebutuhan dana, diharapkan dengan pemenuhan dana yang berasal dari utang dapat mendukung tercapainya target penjualan yang diharapkan perusahaan sehingga laba bagi pemilik perusahaan akan meningkat. Perusahaan memerlukan bahan pertimbangan pengambilan keputusan masa mendatang. Analisis laporan keuangan terhadap kinerja keuangan perusahaan periode yang lalu, dapat digunakan sebagai bahan pertimbangan tersebut. Ukuran yang sering digunakan dalam analisis keuagan adalah rasio.

Debt Ratio $(D R)$ berasal dari utang perusahaan yang dipinjam dibandingkan dengan aktiva. Penggunaan jumlah utang perusahaan tergantung pada keberhasilan pendapatan dan ketersediaan aktiva yang bisa digunakan sebagai jaminan utang (Petty \& Scott, 2011:83). Semakin tinggi nilai rasio ini, jumlah modal pinjaman yang digunakan dalam menghasilkan keuntungan bagi perusahaan juga tinggi.

Debt to Equity Ratio (DER) digunakan untuk menilai keseluruhan jumlah utang (jangka pendek atau jangka panjang) yang dibandingkan dengan seluruh ekuitas. Bagi kreditor, semakin besar rasio ini semakin besar risiko kegagalan yang mungkin terjadi pada perusahaan. Bagi perusahaan semakin rendah nilai rasio DER, semakin tinggi pendanaan yang berasal dari pemilik dan semakin besar batas pengaman bagi peminjam jika rugi atau penyusutan terhadap aktiva (Kasmir, 2014:158).

$R O E$ kemungkinan besar satu-satunya rasio keuangan terpenting yang dimiliki yang merupakan penggerak yang baik bagi nilai perusahaan (Walsh, 2004:60). Bagi pemilik perusahaan, semakin besar pengembalian yang diperoleh, maka perusahaan dianggap berhasil. Apabila dihubungkan dengan utang, maka dengan penggunaan utang diharapkan akan memperbesar pengembalian atas ekuitas atau ROE. 
Perusahaan jika terjadi perubahan kondisi ekonomi, maka kecenderungaan perubahan laba bersih perusahaan yang menggunakan utang lebih tinggi dibandingkan dengan perusahaan yang sedikit menggunakan utang (Sudana, 2009:211). Hal ini memperlihatkan bahwa adanya hubungan yang cukup kuat antar utang yang merupakan salah satu indikator pengukuran $D R$ dan $D E R$ terhadap laba yang terlihat pada perhitungan $R O E$. Rasio-rasio keuangan yang berhubungan dengan pendayagunaan sumber dana dari utang menggambarkan posisi keuangan perusahaan. Perusahaan dapat menggunakan pengaruh Debt Ratio (DR) dan Debt to Equity Ratio (DER) terhadap Return On Equity (ROE) untuk membantu dalam menentukan pemenuhan kebutuhan dana khususnya dari utang sehingga tujuan memakmurkan pemilik dapat tercapai.

Industri property dan realestate merupakan industri yang bergerak dibidang pembangunan gedung-gedung. Tahun 2014, keadaan pasar property di Indonesia mengalami pertumbuhan negatif dan diperkirakan akan terus berlanjut hingga tahun 2015. Faktor penyebabnya yaitu kondisi makro ekonomi yang melambat hanya 5,1\% - 5,5\%, suku bunga acuan (BI rate) berada pada level 7,5\% yang membuat suku bunga kredit tidak kompetitif karena mahal, fluktuasi rupiah yang menembus RP 12.000/ \$1, inflasi sebesar 4\%, serta kenaikan harga BBM. Selain itu, terdapat kendala Indonesia belum memiliki daya saing investasi asing sektor properti karena infrastruktur yang minim, penentuan harga yang terkadang lebih tinggi dari harga pasar, bunga pinjaman yang tinggi, serta rumitnya perizinan (www.properti.kompas.com).

Berdasarkan dari semua latar belakang di atas, maka penelitian ini bertujuan untuk menjelaskan pengaruh debt ratio dan debt to equity ratio terhadap return on equity perusahaan property dan real estate di Bursa Efek Indonesia.

\section{TINJUAN PUSTAKA}

\section{Debt Ratio}

Debt Ratio (DR) adalah utang perusahaan yang dipinjam dibandingkan dengan aktiva. Penggunaan jumlah utang perusahaan tergantung pada keberhasilan pendapatan dan ketersediaan aktiva yang bisa digunakan sebagai jaminan utang dan seberapa resiko yang diasumsikan oleh pihak manajemen (Petty \& Scott, 2011:83). Rumus perhitungan DR, yaitu:

$$
D R=\frac{\text { total utang }}{\text { total aktiva }} \times 100 \%
$$

Berlandaskan hasil dari perhitungan DR, kreditor lebih menyukai rasio utang yang rendah karena makin rendah rasio utang semakin besar perlindungan terhadap kerugian kreditor jika terjadi likuidasi tetapi sebaliknya pemegang saham menginginkan lebih banyak leverage untuk memperbesar laba yang diharapkan. Perusahaan dengan rasio utang diatas rata-rata industri menjadi tanda bahaya karena akan sulit bagi perusahaan meminjam tambahan dana tanpa harus menghimpun ekuitas terlebih dahulu (Brigham \& Houston, 2010:143).

\section{Debt to Equity Ratio}

Debt to Equity (DER) digunakan untuk menilai keseluruhan jumlah utang (jangka pendek atau jangka panjang) yang dibandingkan dengan seluruh ekuitas. Bagi kreditor, semakin besar rasio semakin besar risiko kegagalan yang mungkin 
terjadi pada perusahaan. Bagi perusahaan semakin rendah nilai rasio, semakin tinggi pendanaan yang berasal dari pemilik dan semakin besar batas pengaman bagi peminjam jika rugi atau penyusutan terhadap aktiva (Kasmir, 2014:158). ). Rumus perhitungan DER, yaitu:

$$
\text { DER }=\frac{\text { total utang }}{\text { ekuitas }} \times 100 \%
$$

Ketika perusahaan meningkatkan utangnya, perusahaan berkomiten untuk menanggung arus kas keluar tetap dan tidak menjamin arus kas masuk pasti. Karena itu, semakin besar simpanan semakin besar resiko, namun hal ini juga bergantung pada biaya relatif. Adanya penambahan utang ke dalam neraca apabila biaya utang lebih kecil daripada ekuitas diharapkan meningkatkan profitabilitas dan menaikkan harga saham sehingga meningkatkan kesejahteraan para pemegang saham dan peningkatan pertumbuhan perusahaan (Walsh, 2004:123).

\section{Return On Equity}

Return On Equity (ROE) mengukur pengembalian absolut yang diberikan perusahaan kepada para pemegang saham. ROE yang baik akan membawa keberhasilan bagi perusahaan yang mengakibatkan tingginya harga saham dan membuat perusahaan dapat dengan mudah menarik dana baru. Adanya dana baru memungkinkan perusahaan untuk berkembang, menciptakan kondisi pasar yang sesuai, dan pada gilirannya akan memberikan laba yang lebih besar. Semua hal tersebut dapat menciptakan nilai yang tinggi dan pertumbuhan yang berkelanjutan atas kekayaan para pemiliknya (Walsh, 2004:56). Rumus perhitungan ROE, yaitu:

$$
R O E=\frac{\text { laba bersih sesudah pajak }}{\text { ekuitas }} \times 100 \%
$$

ROE yang tinggi mencerminkan penerimaan perusahaan atas peluang investasi yang baik dan manajemen biaya yang efektif. Namun, ketika perusahaan menerapkan tingkat utang yang tinggi maka ROE hanyalah asumsi risiko keuangan yang berlebihan. Pencarian penyebab timbulnya masalah pada ROE dapat dilakukan dengan cara membandingan perusahaan lain yang sejenis (Horne \& Wachowicz, 2012:184).

\section{Pengaruh Debt Ratio dan Debt To Equity Ratio, terhadap Return On Equity}

Debt Ratio (DR) dan Debt To Equity Ratio (DER) merupakan beberapa bagian dari utang (leverage). Perusahaan sering menggunakan leverage dalam pendanaannya. Dampak perusahaan yang menggunakan leverage, yaitu (Brigham \& Huston, 2011:140):

1. Menghimpun dana melalui utang, pemegang saham dapat mengendalikan perusahaan dengan jumlah investasi ekuitas yang terbatas.

2. Kreditor melihat ekuitas atau dana yang diberikan oleh pemilik sebagai batas pengamanan. jadi semakin tinggi proporsi total modal yang diberikan oleh pemegang saham, makin kecil risiko yang dihadapi kreditor.

3. Jika hasil yang diperoleh asset perusahaan lebih tinggi daripada tingkat bunga yang dibayarkan, maka penggunaan utang akan mengungkit leverage atau memperbesar pengembalian atas ekuitas atau ROE.

Sudana (2009:210) mengemukakan pendapatanya mengenai pengaruh leverage terhadap $R O E$, yaitu: 
1. Kondisi ekonomi suatu perusahaan memburuk pada umumnya ketika suku bunga pinjaman semakin tinggi, sedangkan penjualan dan laba yang diperoleh perusahaan semakin menurun menyebabkan kemampuan perusahaan dalam menghasilkan laba dengan menggunakan utang lebih rendah daripada tingkat bunga yang harus dibayarkan oleh perusahaan.

2. Kondisi ekonomi perusahaan baik, tingkat suku bunga pinjaman rendah, sedangkan penjualan dan laba yang didapat oleh perusahaan meningkat. Kemampuan perusahaan dalam menghasilkan laba yang diperoleh melalui sumber dana utang, lebih besar dari tingkat bunga yang dibayarkan.

3. Kondisi ekonomi perusahaan normal, awalnya peningkatan penggunaan utang akan meningkatkan kemampuan perusahaan dalam menghasilkan laba bagi pemegang saham karena tingkat suku bunga relatif rendah. Namun, ketika perusahaan terus menambah utang, maka akan membuat tingkat suku bunga meningkat. Peningkatan penjualan pada kondisi ekonomi normal relatif lebih rendah dibandingkan kondisi ekonomi baik, sehingga kemampuan perusahaan dalam memperoleh laba juga relatif lebih rendah. Ketika utang yang digunakan sudah melebihi jumlah tertentu dan batas kemampuan perusahaan, kemampuan perusahaan dalam menghasilkan laba akan lebih kecil dibandingkan dengan tingkat suku bunga yang dibayar oleh perusahaan.

\section{Hipotesis:}

H1: Debt Ratio secara parsial berpengaruh terhadap Return On Equity.

H2: Debt to Equity Ratio secara parsial berpengaruh terhadap Return On Equity.

H3: Debt Ratio dan Debt to Equity Ratio secara simultan Debt Ratio dan Debt to Equity Ratio terhadap Return On Equity.

\section{METODE PENELITIAN}

\section{Jenis Penelitian}

Jenis penelitian yang digunakan adalah explanatory research yaitu penelitian yang bertujuan menjelaskan atau membuktikan pengaruh antar variabel yang menjelaskan kejadian tertentu (Zulganef, 2008:11).

\section{Konsep, Variabel, dan Pengukuran}

Konsep adalah unsur penelitian yang terpenting serta generalisasi dari sekelompok fenomena tertentu, sehingga menggambarkan berbagai fenomena yang sama (Singarimbun dan Effendi, 2009:17).

Variabel-variabel dalam penelitian ini yaitu:

1. Variabel Bebas (Independen)

Variabel bebas adalah variabel yang mempengaruhi atau penyebab berubah atau timbulnya variabel terikat (dependen) (Darmawan, 2013:109). Variabel bebas dalam penelitian ini berupa Debt Ratio (DR) dan Debt to Equity Ratio (DER).

2. Variabel Terikat (Dependen)

Variabel terikat merupakan variabel yang dipengaruhi atau yang menjadi akibat dari adanya variabel bebas (independen) (Darmawan, 2013:109). Variabel terikat dalam penelitian ini yaitu Return On Equity (ROE).

\section{Populasi dan Sampel}


Menurut Sugiyono populasi adalah wilayah generalisasi yang terdiri atas: objek/subjek yang mempunyai kualitas atau karakteristik tertentu yang ditetapkan oleh peneliti untuk dipelajari dan kemuadian ditarik kesimpulanya (Agung, 2012:32). Populasi penelitian ini adalah perusahaan Property dan Real Estate di BEI hingga akhir tahun 2013 sejumlah 46 (empat puluh enam) perusahaan.

Sampel adalah bagian dari jumlah dan karakteristik yang dimiliki oleh populasi tersebut. Alasan adanya pengambilan sampel dapat menghasilkan informasi yang lebih luas atau menyeluruh artinya dengan meneliti sejumlah sampel maka tersedianya waktu, tenaga, dan biaya akan lebih memadai untuk mengkaji lebih mendalam obyek penelitian tersebut (Agung, 2012:32). Sampel penelitian ini sebanyak 11 perusahaan Property dan Real Estate di BEI.

Teknik pengambilan sampel yang digunakan adalah sampling nonprobabilitas yaitu sampling purposive. Adapun pertimbangan tertentu yang diambil sampel yaitu:

1. Perusahaan sektor property dan real estate di BEI periode 2010-2013 yang menerbitkan laporan keuangan yang berakhir tanggal 31 Desember dan telah diaudit oleh akuntan publik .

2. Terdapat data yang diperlukan oleh peneliti pada tahun 2010-2013.

\section{Teknik Pengumpulan Data}

Penelitian menggunakan sumber data sekunder dari Bursa Efek Indonesia. Data berupa angka yang digunakan berasal dari laporan keuangan tahun berikutnya yaitu tahun 2010 pada tahun 2011, tahun 2011 pada tahun 2012, tahun 2012 pada tahun 2013. Laporan keuangan perusahaan tahun berikutnya dipilih karena selalu menyajikan kembali laporan keuangan tahun sebelumnya dengan adanya revisi atau penyesuaian. Teknik pengumpulan data yang digunakan yaitu dokumentasi.

\section{Analisis Data}

Analisis data pada penelitian ini menggunakan pendekatan kuantitatif dan analisis data menggunakan bantuan dari program SPSS.

\section{Statistik Deskriptif}

Statistik deskriptif meliputi data mentah yang diolah dengan mengurutkan atau memanipulasi ke dalam penjelasan yang memberikan informasi sekumpulan faktor dalam suatu situasi (Weygant dkk, 2006:285).

\section{Statistik Inferensial}

Statistik inferensial digunakan untuk menganalisis data beberapa variabel bebas yang menjelaskan varians dalam suatu variabel terikat (Weygant dkk, 2006:291). Statistik inferensial terdiri dari:

a. Analisis Regresi Linier Berganda

Analisis regresi linier berganda dilakukan untuk menguji pengaruh dari beberapa variabel bebas terhadap satu variabel terikat (Weygant dkk, 2006:299).

\section{b. Uji Asumsi Klasik}

Sampel yang diambil tidak selamanya memiliki normalitas data. Beberapa penyimpangan normalitas yang dihadapi saat perhitungan analisis regresi berganda yaitu multikoleinearitas, heterokedastisitas, dan autokorelasi.

\section{c. Uji Hipotesis}


Pengujian secara hipotesis dilakukan secara statistik berdasarkan pada uji-T dan uji-F. Pengujian hipotesis terdiri dari dua macam yaitu hipotesis nol $\left(\mathrm{H}_{0}\right)$ dan hipotesis kerja $(\mathrm{Ha})$. Hipotesis nol $\left(\mathrm{H}_{0}\right)$ merupakan hipotesis yang berlawanan dengan teori yang akan dibuktikan sebaliknya, hipotesis kerja (Ha) merupakan hipotesis yang berhubungan dengan teori yang akan dibuktikan.

\section{HASIL DAN PEMBAHASAN}

Analisis Statistik Deskriptif

Debt Ratio (DR)

Tabel 1

Deskriptif Debt Ratio (DR) Perusahaan Property dan Real Estate di BEI (dalam desimal)

\begin{tabular}{|l|l|l|l|l|l|l|}
\hline \multirow{2}{*}{ No. } & \multirow{2}{*}{ Nama Perusahaan } & \multicolumn{3}{|l|}{ Tahun } & Rata- \\
\cline { 3 - 7 } & & $\mathbf{2 0 1 0}$ & $\mathbf{2 0 1 1}$ & $\mathbf{2 0 1 2}$ & $\mathbf{2 0 1 3}$ & rata \\
\hline 1 & PT. Agung Podomoro Land, Tbk & 0,46 & 0,54 & 0,58 & 0,63 & 0,57 \\
\hline 2 & PT. Bekasi Asri Pemula, Tbk & 0,45 & 0,45 & 0,45 & 0,47 & 0,46 \\
\hline 3 & PT. Bumi Citra Permai, Tbk & 0,20 & 0,23 & 0,44 & 0,48 & 0,37 \\
\hline 4 & PT. Ciputra Developent, Tbk & 0,23 & 0,34 & 0,44 & 0,51 & 0,41 \\
\hline 5 & PT. Ciputra Surya, Tbk & 0,35 & 0,45 & 0,50 & 0,57 & 0,49 \\
\hline 6 & PT. Cowell Development, Tbk & 0,51 & 0,58 & 0,36 & 0,39 & 0,40 \\
\hline 7 & PT. Intiland Development, Tbk & 0,21 & 0,33 & 0,35 & 0,46 & 0,35 \\
\hline 8 & PT. Kawasan Industri Jabaneka, Tbk & 0,50 & 0,37 & 0,44 & 0,49 & 0,45 \\
\hline 9 & PT. MNC Land, Tbk & 0,07 & 0,07 & 0,19 & 0,17 & 0,15 \\
\hline 10 & PT. Perdana Gapuraprima, Tbk & 0,49 & 0,47 & 0,46 & 0,40 & 0,45 \\
\hline 11 & PT. Summarecon Agung, Tbk & 0,65 & 0,69 & 0,65 & 0,66 & 0,66 \\
\hline & Rata-rata Industri & 0,46 & 0,48 & 0,51 & 0,54 & 0,50 \\
\hline & Pertumbuhan (g) & & 0,05 & 0,06 & 0,06 & \\
\hline & Nilai Tertinggi & 0,65 & 0,69 & 0,65 & 0,64 & 0,84 \\
\hline & Nilai Terendah & 0,07 & 0,07 & 0,19 & 0,17 & 0,15 \\
\hline
\end{tabular}

Sumber: Data Diolah (2017)

Berdasarkan tabel 1 dapat diketahui bahwa rata-rata $D R$ perusahaan sampel selama periode penelitian 2010-2013 sebesar 50\%. Perusahaan yang memiliki $D R$ diatas rata-rata industri periode 2010-2013 adalah PT. Summarecon Agung, Tbk sebesar 66\%; dan Agung Podomoro Land, Tbk 57\% dan untuk pertumbuhan $D R$ dari rata-rata industri pertahunnya pada tahun 2010 ke tahun 2011 sebesar 5\%, tahun 2011 ke tahun 2012 dan tahun 2012 ke tahun 2013 sebesar $6 \%$.

Debt to Equity Ratio (DER)

Tabel 2

Deskripstif Debt to Equity Ratio (DER) Perusahaan Property dan Real Estate di BEI (dalam desimal)

No. Nama Perusahaan

Tahun Rata- 


\begin{tabular}{|l|l|l|l|l|l|l|}
\cline { 3 - 6 } & & $\mathbf{2 0 1 0}$ & $\mathbf{2 0 1 1}$ & $\mathbf{2 0 1 2}$ & $\mathbf{2 0 1 3}$ & rata \\
\hline 1 & PT. Agung Podomoro Land, Tbk & 0,84 & 1,15 & 1,39 & 1,73 & 1,34 \\
\hline 2 & PT. Bekasi Asri Pemula, Tbk & 0,82 & 0,83 & 0,82 & 0,90 & 0,84 \\
\hline 3 & PT. Bumi Citra Permai, Tbk & 0,25 & 0,30 & 0,77 & 0,92 & 0,59 \\
\hline 4 & PT. Ciputra Developent, Tbk & 0,29 & 0,51 & 0,77 & 1,06 & 0,69 \\
\hline 5 & PT. Ciputra Surya, Tbk & 0,55 & 0,81 & 1,00 & 1,31 & 0,96 \\
\hline 6 & PT. Cowell Development, Tbk & 1,05 & 1,35 & 0,57 & 0,64 & 0,68 \\
\hline 7 & PT. Intiland Development, Tbk & 0,27 & 0,50 & 0,54 & 0,84 & 0,55 \\
\hline 8 & PT. Kawasan Industri Jabaneka, Tbk & 1,00 & 0,60 & 0,78 & 0,97 & 0,82 \\
\hline 9 & PT. MNC Land, Tbk & 0,07 & 0,08 & 0,23 & 0,21 & 0,17 \\
\hline 10 & PT. Perdana Gapuraprima, Tbk & 0,94 & 0,90 & 0,86 & 0,66 & 0,83 \\
\hline 11 & PT. Summarecon Agung, Tbk & 1,86 & 2,27 & 1,85 & 1,93 & 1,96 \\
\hline & Rata-rata Industri & 1,29 & 1,44 & 1,54 & 1,71 & 1,50 \\
\hline & Pertumbuhan (g) & & 0,12 & 0,07 & 0,11 & \\
\hline & Nilai Tertinggi & 4,68 & 5,17 & 5,67 & 5,28 & 5,24 \\
\hline & Nilai Terendah & 0,07 & 0,08 & 0,23 & 0,21 & 0,17 \\
\hline
\end{tabular}

Sumber: Data Diolah (2017)

Berdasarkan tabel 2 dapat diketahui bahwa rata-rata $D E R$ perusahaan sampel selama periode penelitian sebesar $150 \%$. Perusahaan yang memiliki $D E R$ diatas rata-rata industri periode 2010-2013 adalah PT. Summarecon Agung, Tbk 196\%;. Berdasarkan rasio pertumbuhan rata-rata industri, pada tahun 2010 ke 2011 meningkat 12\%, pada tahun 2011 ke 2012 sebesar 7\% demikian pula dari tahun 2012 ke 2013 mengalami peningkatan sebesar $11 \%$.

Tabel 3

Deskriptif DR dan DER dan ROE Perusahaan Property dan Real Estate di BEI periode 2010-2013

\begin{tabular}{|l|l|l|l|l|l|}
\hline & $\mathrm{N}$ & Minimum & Maximum & Mean & Std. Deviation \\
\hline$D R$ & 11 & .07 & .85 & .4997 & .19676 \\
\hline$D E R$ & 11 & .07 & 5.67 & 1.4960 & 1.43954 \\
\hline$R O E$ & 11 & .83 & 26.38 & 10.9985 & 6.29806 \\
\hline Valid N (listwise) & 11 & & & & \\
\hline
\end{tabular}

Sumber: Data Diolah (2017)

Nilai minimum, maksimun, dan rata-rata telah tersajikan dalam masingmasing variabel, sedangkan standar deviasi $D R$ sebesar 0,197 DER sebesar 1,43; dan $R O E$ sebesar 6,29.

\section{ANALISIS REGRESI BERGANDA Persamaaan Regresi}

Analisis regresi bertujuan untuk menunjukkan hubungan matematis antara variabel bebas dengan variabel terikat.

Tabel 4

Hasil Uji Coefficients terhadap ROE pada Perusahaan Property dan Real Estate di BEI 
Coefficients $^{\mathbf{a}}$

\begin{tabular}{|c|c|c|c|c|c|c|c|}
\hline \multirow[t]{2}{*}{ Model } & \multicolumn{2}{|c|}{$\begin{array}{l}\text { Unstandardized } \\
\text { Coefficients }\end{array}$} & \multirow{2}{*}{\begin{tabular}{|l|}
$\begin{array}{l}\text { Standardized } \\
\text { Coefficients }\end{array}$ \\
Beta \\
\end{tabular}} & \multirow[t]{2}{*}{$\mathrm{t}$} & \multirow[t]{2}{*}{ Sig. } & \multicolumn{2}{|c|}{$\begin{array}{l}\text { Collinearity } \\
\text { Statistics }\end{array}$} \\
\hline & B & Std. Error & & & & Tolerance & VIF \\
\hline (Constant) & 1.301 & 1.968 & & .657 & .514 & & \\
\hline DR & 13.089 & 5.661 & .408 & 2.312 & .024 & .216 & 4.632 \\
\hline DER & 1.679 & .772 & .383 & 2.174 & .034 & .217 & 4.615 \\
\hline
\end{tabular}

Sumber: Data Diolah (2017)

Berdasarkan tabel 4 menunjukkan persamaan regresi:

$\mathrm{Y}=1,301+0,408 \mathrm{X}_{1}+0,383 \mathrm{X}_{2}$, artinya:

- Nilai konstanta menunjukkan sebesar 1,301 artinya jika nilai variabel bebas (DR dan DER ) nol maka nilai variabel terikat (ROE) sebesar 1,301.

- ROE akan meningkat sebesar 0,408 satuan untuk setiap satuan $\mathrm{X}_{1}$ (DR). Jadi apabila DR mengalami peningkatan 1 satuan, maka ROE akan meningkat sebesar 0,408 satuan dengan asumsi variabel yang lainnya dianggap konstan.

- $\quad$ ROE akan meningkat sebesar 0,383 satuan untuk setiap satuan $\mathrm{X}_{2}$ (DER). Jadi apabila DER mengalami peningkatan 1 satuan, maka ROE akan meningkat sebesar 0,383 satuan dengan asumsi variabel yang lainnya dianggap konstan.

\section{Koefisien Determinasi $\left(\mathbf{R}^{2}\right)$}

Koefisien determinasi digunakan untuk mengetahui ketepatan atau kecocokan garis regresi yang terbentuk dalam mewakili kelompok data hasil penelitian.

Tabel 5

Hasil Uji Koefisiensi Determinasi terhadap ROE Perusahaan Property dan Real Estate di BEI

\begin{tabular}{|l|l|l|l|l|}
\hline Model & $\mathrm{R}$ & R Square & $\begin{array}{l}\text { Adjusted R } \\
\text { Square }\end{array}$ & $\begin{array}{l}\text { Std. Error of } \\
\text { the Estimate }\end{array}$ \\
\hline 1 & $.789^{\mathrm{a}}$ & .622 & .602 & 3.97505 \\
\hline
\end{tabular}

Sumber: Data Diolah (2017)

Berdasarkan Tabel 5, hasil dari analisis korelasi varibael bebas ( $D R$ dan $D E R$ ) terhadap variabel terikat $(R O E)$ pada sektor property dan real estate memiliki nilai korelasi berganda (R) 0,789, artinya korelasi sederhana (korelasi Pearson) antara variabel bebas terhadap variabel terikat sebesar 0,789 sehingga terjadi hubungan erat karena nilai mendekati 1. Penelitian ini menggunakan Adjusted $R$ Square karena dalam regresi menggunakan lebih dari dua variabel bebas. Nilai koefisien determinasi (Adjusted $R$ Square / $\mathrm{R}^{2}$ ) sebesar 0,622 berarti bahwa variabel DR dan DER berpengaruh sebesar 62,2\% terhadap ROE, sedangkan sisanya yaitu $37,8 \%$ dijelaskan oleh variabel lain diluar model regresi penelitian.

\section{Analisis Statistik Inferensial}

Berikut disajikan tabel hasil uji kolmogorov smirnov pada sektor property dan real estate.

Tabel 6

Hasil Uji Kolmogorov-Smirnov terhadap ROE pada Perusahaan Sektor Property dan Real Estate go public di BEI 


\begin{tabular}{|l|l|l|}
\hline \multicolumn{2}{|l|}{} & Unstandardized Residual \\
\hline \multirow{2}{*}{ Normal Parameters } & a,b & 33 \\
\cline { 2 - 3 } & Mean & .0000000 \\
\cline { 2 - 3 } $\begin{array}{l}\text { Most Extreme } \\
\text { Differences }\end{array}$ & Std. Deviation & 3.87267156 \\
\cline { 2 - 3 } & Absolute & .109 \\
\hline Kolmogorov-Smirnov Z & Negative & .109 \\
\hline Kolme & -.089 \\
\hline Asymp. Sig. (2-tailed) & .842 \\
\hline
\end{tabular}

Sumber: Data Diolah (2017)

Hasil uji Kolmogorov Smirnov pada Tabel 6, menunjukkan hasil Asymp. Sig. (2-tailed) lebih dari 0,05, yaitu sebesar 0,477. Suatu data dikatakan terdistribusi secara normal jika nilai dari Asymp. Sig. (2-tailed) $\geq 0,05$. Berdasarkan hasil tersebut dapat disimpulkan bahwa data telah terdistribusi secara normal.

\section{UJI HIPOTESIS}

\section{Hipotesis Pertama}

Uji parsial (uji t) variabel Debt Ratio $(D R)$ digunakan untuk mengetahui apakah secara parsial $D R$ berpengaruh secara signifikan atau tidak terhadap $R O E$. Kriteria pengujian jika $-\mathrm{t}$ tabel $\leq \mathrm{t}$ hitung $\leq \mathrm{t}$ tabel maka $\mathrm{H}_{0}$ diterima, jika $-\mathrm{t}$ hitung $<-\mathrm{t}$ tabel atau $\mathrm{t}$ hitung $>\mathrm{t}$ tabel maka $\mathrm{H}_{0}$ ditolak. Berdasarkan signifikansi jika sig. $>$ 0.05 maka $\mathrm{H}_{0}$ diterima, jika sig, < 0,05, maka $\mathrm{H}_{0}$ ditolak. Tabel pada uji t berasal dari tabel uji coefficients dan disajikan kembali secara individu.

Perumusan Hipotesis :

- $\mathrm{H}_{0}: D R$ secara parsial tidak berpengaruh terhadap $R O E$.

- Ha : $D R$ secara parsial berpengaruh terhadap $R O E$.

Tabel 7

Uji t $D R$ terhadap $R O E$ pada Perusahaan Sektor Property dan Real di BEI

\begin{tabular}{|l|l|l|}
\hline Model & $\mathbf{t}$ & Sig \\
\hline$D R$ & 2.411 & .022 \\
\hline
\end{tabular}

Sumber: Data Diolah (2017)

Tabel 7 di dapat $t$ hitung sebesar 2,411 dan signifikansi 0,022. $t$ tabel yang diperoleh dari tabel statistik pada signifikansi $0,050 / 2=0,025$ dengan derajat kebebasan $\mathrm{df}=\mathrm{n}-\mathrm{k}-1$ atau 11-3-1 = 7, hasil diperoleh untuk $\mathrm{t}$ tabel sebesar 2,364. Nilai t hitung > t tabel $(2,411>2,364)$ dan Sig. $<0,05(0,022<0.050)$ maka $\mathrm{H}_{0}$ ditolak, jadi dapat disimpulkan bahwa $D R$ secara parsial berpengaruh terhadap $R O E$. Nilai t hitung positif artinya berpengaruh positif, yaitu jika $D R$ meningkat, maka $R O E$ juga akan meningkat.

\section{Hipotesis Kedua}

Uji parsial (uji t) variabel Debt to Equity Ratio (DER) digunakan untuk mengetahui apakah secara parsial $D E R$ berpengaruh secara signifikan atau tidak terhadap ROE. Kriteria pengujian jika $-\mathrm{t}$ tabel $\leq \mathrm{t}$ hitung $\leq \mathrm{t}$ tabel maka $\mathrm{H}_{0}$ diterima, jika $-\mathrm{t}$ hitung $<-\mathrm{t}$ tabel atau $\mathrm{t}$ hitung $>\mathrm{t}$ tabel maka $\mathrm{H}_{0}$ ditolak. Berdasarkan signifikansi jika sig. $>0.05$ maka $\mathrm{H}_{0}$ diterima, jika sig, < 0,05, maka 
$\mathrm{H}_{0}$ ditolak. Tabel pada uji $\mathrm{t}$ berasal dari tabel uji coefficients yang ditampilkan kembali secara individu.

Perumusan Hipotesis :

- $\mathrm{H}_{0}$ : DER secara parsial tidak berpengaruh terhadap $R O E$.

- Ha : DER secara parsial berpengaruh terhadap ROE.

Tabel 8

Uji t DER terhadap ROE pada Perusahaan Property dan Real Estate di BEI

\begin{tabular}{|l|l|l|}
\hline Model & $\mathbf{t}$ & Sig \\
\hline$D E R$ & 2.474 & .033 \\
\hline
\end{tabular}

Sumber : Data Diolah (2017)

Tabel 8 di dapat $t$ hitung sebesar 2,474 dan signifikansi 0,033. $t$ tabel yang diperoleh dari tabel statistik pada signifikansi $0,050 / 2=0,025$ dengan derajat kebebasan $\mathrm{df}=\mathrm{n}-\mathrm{k}-1$ atau 60-3-1 = 56, hasil diperoleh untuk t tabel sebesar 2,364. Nilai t hitung > t tabel $(2,474>2,364)$ dan Sig. $<0,05(0,034<0.050)$ maka $\mathrm{H}_{0}$ ditolak, jadi dapat disimpulkan bahwa $D E R$ secara parsial berpengaruh terhadap $R O E$. Nilai t hitung positif artinya berpengaruh positif, yaitu jika $D E R$ meningkat, maka $R O E$ juga akan meningkat.

\section{Hipotesis Ketiga}

Anova atau analisis varian, yaitu uji koefisisen regresi secara simultan (uji F) untuk menguji signifikansi pengaruh beberapa varianel bebas terhadap variabel terikat. Pengujian menggunakan tingkat signifikansi 0,05.

\section{Tabel 9}

Uji F terhadap ROE Perusahaan Property dan Real Estate di BEI

\begin{tabular}{|l|l|l|l|l|l|l|}
\hline \multicolumn{2}{|l|}{ Model } & $\begin{array}{l}\text { Sum of } \\
\text { Squares }\end{array}$ & df & $\begin{array}{l}\text { Mean } \\
\text { Square }\end{array}$ & F & Sig. \\
\hline \multirow{3}{*}{1} & Regression & 1455.407 & 3 & 485.136 & 30.601 & $.000^{\mathrm{b}}$ \\
\cline { 2 - 8 } & Residual & 884.858 & 56 & 15.801 & & \\
\cline { 2 - 7 } & Total & 2340.264 & 59 & & & \\
\hline
\end{tabular}

Sumber: Data Diolah (2017)

Tabel 9 diperoleh $\mathrm{F}$ hitung sebesar 30,701 dan nilai Signifikansi sebesar 0,000. F tabel dari tabel statistik pada tingkat Signifikansi 0,05 dengan df $1=3$, dan df $2(\mathrm{n}-\mathrm{k}-1)=11-3-1=7$ ( $\mathrm{n}$ adalah jumlah data dan $\mathrm{k}$ adalah jumlah variabel bebas), hasil diperoleh $\mathrm{F}$ tabel sebesar 4,35. Kriteria pengujian $\mathrm{F}$ hitung $\leq \mathrm{F}$ tabel maka $\mathrm{H}_{0}$ diterima, jika $\mathrm{F}$ hitung $>\mathrm{F}$ tabel maka $\mathrm{H}_{0}$ ditolak. $\mathrm{F}$ hitung $>\mathrm{F}$ tabel $(30,601>4,35)$ dan Signifikansi $<0,05(0,00<0,05)$, maka $\mathrm{H}_{0}$ ditolak jadi dapat disimpulkan bahwa DR dan DER secara bersama-sama berpengaruh terhadap ROE.

\section{Interprestasi dan Pembahasan}

Dari hasil analisis regresi linier berganda diketahui bahwa terdapat hubungan yang cukup kuat sebesar $78,9 \%$ antara variabel bebas $D R$ dan $D E R$ terhadap variabel terikat ROE. Disamping itu pengaruh variabel bebas terhadap variabel 
terikat juga cukup besar yaitu $62,2 \%$ sedangkan sisanya sebesar $37,8 \%$ dipengaruhi variabel lain di luar dua variabel tersebut.

1. Debt Ratio $(D R)$

Dari tabel di atas dapat diketahui bahwa secara umum rata-rata Debt Ratio (DR) selama periode penelitian 2010-2013 sebesar 50\%. Artinya, rata-rata perusahaan sektor property dan real estate relatif aman karena dipercayai oleh para kreditor yang beranggapan bahwa perusahaan-perusahaan tersebut akan dapat membayar kewajiban jangka pendek yang akan jatuh tempo dengan aktiva yang dimiliki perusahaan.

Hasil analisis koefisien regresi parsial pada tabel 4 memperlihatkan $D R$ sebesar 0,408 yang artinya apabila $D R$ mengalami peningkatan 1 satuan, maka $R O E$ akan meningkat sebesar 0,408 satuan dengan asumsi variabel yang lainnya dianggap konstan. Hasil uji t pada tabel 7 menunjukkan variabel ini signifikan karena probabilitas kurang dari 0,050 yaitu 0,022 ; artinya secara statistik variabel $D R$ signifikan dalam menentukan $R O E$.

2. Debt to Equity Ratio (DER)

Debt to Equity Ratio (DER) merupakan perbandingan antara total utang dengan ekuitas. Pemenuhan kebutuhan dana yang sehat, dibangun atas dasar modal sendiri (dalam peneltian ini disebut ekuitas) karena tahan resiko. Aturan struktur finansiil yang konservatif yang vertikal menetapkan bahwa besarnya koefisien utang yaitu angka perbandingan antara utang dengan modal sendiri tidak boleh melebihi 1 : 1. Dari tabel 6 dapat diketahui bahwa secara umum rata-rata $D E R$ perusahaan sektor property dan real estate selama periode penelitian 2010-2013 sebesar 150\% yang melebihi dari koefisien utang sehingga dianggap kurang baik.

Hasil analisis koefisien regresi parsial pada tabel 4 memperlihatkan DER sebesar 0,383 yang artinya apabila $D E R$ mengalami peningkatan 1 satuan, maka $R O E$ akan meningkat sebesar 0,384 satuan dengan asumsi variabel yang lainnya dianggap konstan. Hasil uji t tabel 8 menunjukkan variabel ini signifikan karena probabilitas lebih kecil dari 0,050 yaitu 0,033 ; artinya secara statistik variabel $D E R$ signifikan dalam menentukan $R O E$.

\section{KESIMPULAN}

1. Secara parsial dapat dijelaskan bahwa variabel debt ratio $(D R)$ berpengaruh terhadap return on equity (ROE).

2. Secara parsial dapat dijelaskan bahwa variabel debt to equity ratio (DER) berpengaruh terhadap return on equity (ROE).

3. Variabel debt ratio (DR) dan debt to equity ratio (DER) secara simultan berpengaruh signifikan terhadap variabel terikat return on equity (ROE). Hasil ini menunjukkan bahwa secara bersama-sama variabel bebas tersebut telah mampu memberikan kontribusi terhadap return on equity (ROE).

\section{SARAN}

1. Variabel debt to equity ratio (DER) berpengaruh paling dominan terhadap return on equity (ROE), maka variabel debt to equity ratio (DER) perlu mendapatkan perhatian. Meningkatnya debt to equity ratio (DER) akan 
memberikan kontribusi yang positif terhadap return on equity (ROE), sehingga akan terlihat bahwa kondisi perusahaan baik.

2. Diharapkan penelitian selanjutnya untuk memasukkan variabel-variabel lain juga mengingat dari nilai koefisien determinasi hanya sebesar 60,2\%.

\section{DAFTAR PUSTAKA}

Agung, Anak Agung Putu. 2012. Metodologi Penelitian Bisnis. Malang : UB Press.

. 2014. “ Ini Empat Kendala Investasi Asing di Pasar Indonesia”, diakses pada Tanggal 9 Mei 2017 dari http://properti.kompas.com /index.php/read/2014/10/08/120004021/Ini.Empat.Kendala.Investasi.Asin g.di.Pasar.Properti.Indonesia.

Brigham, F. dan Joel F. Houston. 2010. Dasar-dasar Manajemen Keuangan, Edisi 11 Buku 1. Jakarta : Salemba Empat. . 2011. Dasar-dasar Manajemen Keuangan, Edisi 11 Buku 2. Jakarta : Salemba Empat.

Darmawan, Deni. 2013. Metode Penelitian Kuantitatif. Bandung : PT. Remaja Rosdakarya.

Horne, James C. Van dan John M. Wachowicz, Jr. 2012. Prinsip-prinsip Manajemen Keuangan, Edisi 13 Buku 1. Jakarta Selatan : Salemba Empat.

Kasmir. 2014. Analisis Laporan Keuangan. Jakarta : PT.Rajagrafindo Persada.

Singarimbun, Masri dan Sofian Effendi. 2009. Metode Penelitian Survai. Jakarta : LP3ES.

Sudana, I Made. 2009. Manajemen Keuangan Teori dan Praktik. Surabaya: Airlangga University Press.

Walsh, Ciaran. 2004. Key Management Ratios. Jakarta : Erlangga.

Weygant, Jerry dkk. 2006. Metode Penelitian untuk Bisnis, Edisi 4. Jakarta : Salemba Empat.

Zulganef. 2008. Metode Penelitian Sosial dan Bisnis. Yogyakarta : Graha Ilmu. 